
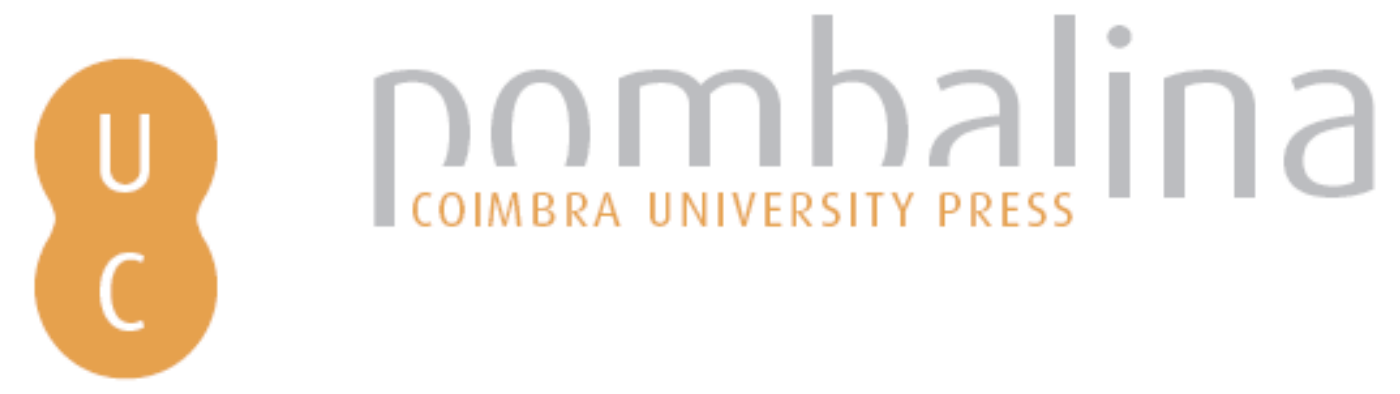

\title{
Zoroastro, o Grego: Zaratustra na percepção grega e helenística
}

Autor(es): $\quad$ Fernandes, Edrisi

Publicado por: Imprensa da Universidade de Coimbra; Annablume

URL

persistente:

URI:http://hdl.handle.net/10316.2/40864

DOI:

DOI:https://doi.org/10.14195/978-989-26-1288-1_7

Accessed : $\quad$ 26-Apr-2023 03:31:50

A navegação consulta e descarregamento dos títulos inseridos nas Bibliotecas Digitais UC Digitalis, UC Pombalina e UC Impactum, pressupõem a aceitação plena e sem reservas dos Termos e Condições de Uso destas Bibliotecas Digitais, disponíveis em https://digitalis.uc.pt/pt-pt/termos.

Conforme exposto nos referidos Termos e Condições de Uso, o descarregamento de títulos de acesso restrito requer uma licença válida de autorização devendo o utilizador aceder ao(s) documento(s) a partir de um endereço de IP da instituição detentora da supramencionada licença.

Ao utilizador é apenas permitido o descarregamento para uso pessoal, pelo que o emprego do(s) título(s) descarregado(s) para outro fim, designadamente comercial, carece de autorização do respetivo autor ou editor da obra.

Na medida em que todas as obras da UC Digitalis se encontram protegidas pelo Código do Direito de Autor e Direitos Conexos e demais legislação aplicável, toda a cópia, parcial ou total, deste documento, nos casos em que é legalmente admitida, deverá conter ou fazer-se acompanhar por este aviso. 


\section{Cosmópolis}

\section{mobilidades culturais às origens do pensamento antigo}

Gabriele Cornelli, Maria do Céu Fialho e Delfim Leão

\section{(coords.)}

IMPRENSA DA UNIVERSIDADE DE COIMBRA 


\title{
Zoroastro, o Grego \\ Zaratustra Na PERCEPÇÃo grega E HELENística \\ [Zoroaster, the Greek - Zarathustra in Greek and Hellenistic perception]
}

\author{
Edrisi Fernandes (edrisi@email.com) \\ UnB - Cátedra Archai UNESCO
}

Resumo: A partir do estudo das fontes clássicas e de reflexões de eruditos modernos, investigamos como se deu a assimilação da figura do sábio, legislador e religioso iraniano Zaratustra (Zarathushtra) na Grécia clássica e no mundo helenístico, e apresentamos nosso entendimento das circunstâncias, mecanismos e consequências dessa assimilação. Nesse processo, destacamos o contraste entre o "fascínio pelo outro" e as reservas ante o estranho, e esmiuçamos a apropriação transformadora do pensamento iraniano no pensamento grego e, particularmente, na nascente filosofia. James R. Russell - professor de estudos iranianos e armênios em Harvard, e um dos estudiosos do papiro de Derveni - afirmou provocativamente em 1989 que "a Grécia estava mais próxima da Pérsia, e tinha mais em comum com ela do que com os norte-europeus que inventaram uma disciplina clamada [Estudos] Clássicos”. A publicação por Phillip Sidney Horky do fascinante trabalho "Persian Cosmos and Greek Philosophy: Plato's Associates and the Zoroastrian Magoi”, em 2009, dá uma boa ideia do quanto se avançou em vinte anos de estudos sobre as trocas culturais entre a Pérsia e a Grécia na antiguidade clássica. É o caso de recapitularmos agora o quanto se progrediu no conhecimento que temos sobre Zaratustra/Zoroastro, centrando nosso foco na rica herança do sábio iraniano nos alvores da história do pensamento ocidental.

Palavras-chave: Cosmópolis; filosofia grega; Zaratustra; Zoroastro; Zoroastrismo

Авsтract: From the study of classical sources and reflections from modern scholars, we have investigated the assimilation of the figure of Zoroaster (Zarathushtra), the Iranian sage, legislator, and religious leader, in classical Greece and the Hellenistic world, and here we present our understanding of the circumstances, mechanisms and consequences of this assimilation. In this process, we highlight the contrast between the "fascination with the other" and reservations toward the stranger, and we scrutinize the transformative appropriation of Iranian thought in Greek thought, particularly in the nascent philosophy. James R. Russell - professor of Iranian and Armenian studies at Harvard, and one of the scholars studying the Derveni Papyrus - teasingly said in 1989 that "Greece was closer to Persia, and had more in common with it, than it did with the northern Europeans who invented a discipline called Classics". The publication by Phillip Sidney Horky of the fascinating work "Persian Cosmos and Greek Philosophy: Plato's Associates and the Zoroastrian Magoi" in 2009 gives a good idea of how much progress has been made in twenty years of studies on cultural exchanges between Persia and Greece in classical antiquity. It is time for a recapitulation on how much our knowledge about Zarathustra/Zoroaster has 
advanced, centering our focus on the rich heritage of the Iranian sage at the dawn of the history of Western thought.

KeYwords: Cosmopolis; Greek philosophy; Zarathustra; Zoroaster; Zoroastrianism

\section{INTRODUÇÃo: PORQUE PISAR DE NOVO UMA SENDA TANTAS VEZES BATIDA?}

Não obstante a inexistência de novas descobertas de fontes ocidentais antigas sobre Zoroastro ${ }^{1}$, contribuições advindas de estudos transdisciplinares, e especialmente do cruzamento dos estudos clássicos com a iranística, permitem novos enfoques que nos capacitam a dimensionar melhor a importância de trabalhos acadêmicos ou de circulação geral que tratam da recepção ocidental de Zaratustra e a entender melhor as circunstâncias e particularidades da mesma.

Marijan Molé, que publicou dois tomos acerca do profeta Zaratustra e de seus ensinamentos, disse o seguinte sobre Zaratustra: "Fundador da mais antiga religião salvífica ${ }^{2}$, pensador asiático conhecido na Europa desde Platão, profeta cujo nome continua a ser venerado pelos parses de Bombaim, e a quem a tradição hermética reclamou como um dos seus mestres - Zoroastro o Spitamid ${ }^{3}$ permanece completamente desconhecido para nós" (Molé 1963: II 271).

Se em 1963 uma respeitada acadêmica proclamava que Zoroastro permanece desconhecido para nós, terá algo mudado após meio século de investigações internacionais sobre esse exótico persa que continua fascinando o imaginário ocidental? A bem da verdade, como afirmou Millar, "até onde concerne a evidência da antiguidade, nosso (suposto) conhecimento [histórico] do Zoroastrismo depende inteiramente, e sem exceção, de representações greco-romanas" (Millar 1988: 523). Phiroze Vasunia, contudo, recorda que "enquanto essas fontes tem sido parte dos estudos religiosos por alguns séculos, debates sobre sua utilidade e significância continuam a graçar sem trégua (to rage unabated). Algumas vezes parece que nunca dois estudiosos do Zoroastrismo podem concordar sobre proposições gerais sobre seu assunto, e muito menos sobre um problema tão vexatório quanto aquele das fontes gregas e latinas" (Vasunia, 2007: 17). Ainda mais difícil é conciliar a

${ }^{1}$ Cf. De Jong 1997: 14.

${ }^{2}$ Conforme Alessandro Bausani, "do ponto de vista comparativista, não é exagerado afirmar que o Zoroastrismo forneceu o material para a construção das lendas escatológicas de todas as grandes religiões do mundo civil [i.e., ocidental]. O Islã, o Judaísmo tardio [posterior ao $2^{\circ}$ templo, incluindo o Judeocristianismo] e, em grande parte, por misteriosas vias, também o mundo das sagas escandinavas e o mundo das lendas medievais cristãs, são indubitavelmente tributários da religiosidade iraniana pelas suas visões angélicas e escatológicas”. Vista a partir de uma perspectiva interna, a Pérsia aparece como uma das fontes mais importantes para se compreender o senso escatológico que influiu profundamente sobre toda a cultura ocidental [A. Bausani (1959), Persia Religiosa da Zaratustra a Bahâ’u'llah. Milão, Il Saggiatore, p. 19].

${ }^{3}$ Que é (cf., p. ex., a Yasna, 46.16) do clã Spitama (contração do superlativo Spitatama, "branquíssimo" - equivalente ao sânscrito Svetatama). De uma atenuação consonantal de p para f, temos hoje, para "branco", o farsi sefid, urdu sefed, hindi safed. 
opinião de iranistas e classicistas, o que não nos impede de esboçar aqui ${ }^{4}$, com a ajuda dos estudos clássicos mas valendo-nos de aportes da iranologia, um retrato de Zoroastro (Zaratustra) na percepção grega e helenística.

\section{Primeiros relatos ocidentais Sobre o zoroastrismo}

Xanto da Lídia (metade do séc. V a.C., anterior a Heródoto) é a fonte mais antiga que dispomos em grego sobre Zoroastro (em avéstico, Zarathushtra, veteroiraniano *Zaratushtra); na sua $\Lambda \cup \delta 1 \alpha \kappa \alpha^{5}$ o nome deste aparecia como Z $\omega \rho \circ \alpha \alpha_{\sigma} \tau \rho \eta \zeta^{6}$. Este nome também aparece no Primeiro Alcibiades ${ }^{7}$ (122a1), e surge subsequen-

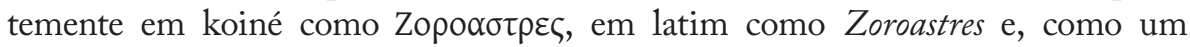

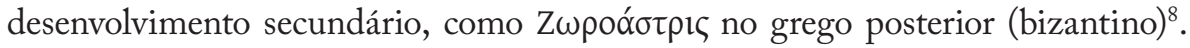
Atribui-se a Xanto (Müller, FHG I Fr. 19) a seguinte citação, reproduzida no século I a.C. por Nicolau de Damasco: "Quanto a Zoroastro, os persas alegam que foi dele que receberam a lei que condena a queima de cadáveres, ou a contaminação do fogo de qualquer outra maneira, e que depois dessa regra ter sido seguida por muito tempo eles finalmente a estabeleceram como um costume" [Jackson 1899: 232; Fox - Pemberton 1929: 1; Bidez - Cumont 1938: II 82 (Fr. D9)].

Pode ser que devamos a Xanto a transposição do nome de Zaratustra para o

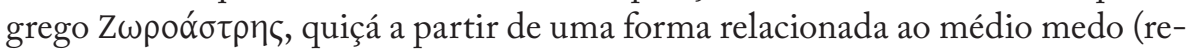
constituído) *Zarahushtra", aproximada ao nome Zarahusht (Zrhwšt), atestado em textos maniqueus em idioma parto ${ }^{10}$. A possibilidade de uma intermediação meda para o contato com o nome do profeta iraniano não é sem importância: segundo Heródoto (I.101), à nação dos medos (veteropersa madai; grego $\mu \eta \delta o l)$ pertencia a tribo dos $\mu$ á үol (vetero-iraniano magush; veteropersa magu-) ${ }^{11}$, que

${ }^{4}$ E enquanto se espera a publicação, no vindouro Blackwell Companion to the Study of Zoroastrianism (ed. Michael Stausberg, Yuhan S.-D. Vevaina), de um prometido capítulo de Martin L. West, intitulado "Zoroastrianism in the Classical World".

${ }^{5}$ Fr. 32 Jacoby.

${ }^{6}$ M. Boyce (1982), A History of Zoroastrianism, II: under the Achaemenians. Leiden, Brill, p. 183; cf. Bidez - Cumont 1938 I 5 e 7.

${ }^{7}$ A atribuição desse diálogo a Platão ainda é objeto de controvérsia. Cf. Jakub Jirsa (2009), "Authenticity of the Alcibiades I: some reflections". Listy Filologické, 132 (3-4): 225-244.

8 Também foram registradas formas variantes mais parecidas com o nome avéstico,

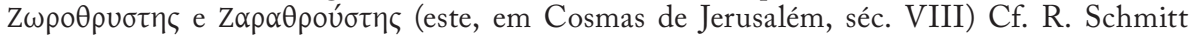
(2002), s.v. "Zoroaster I. The Name" in E. Yarshater (ed.), Encyclopaedia Iranica, Online Edition [disponível em <http://www.iranicaonline.org/ articles/ zoroaster-i-the-name>; acedido a 17/06/2013].

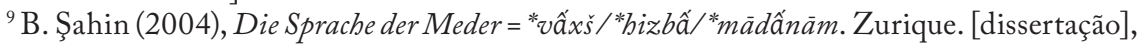
p. 147 [Disponível em <http://bnk.institutkurde.org/images/ pdf/1RGZ3XDKEM.pdf>; acedido a 17/06/2013].

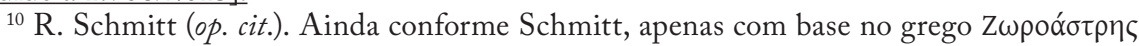
é postulada uma forma veteropersa *Zaraushtra. Uma transposição direta do avéstico

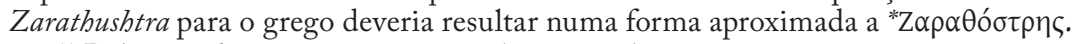

${ }^{11}$ Relacionados ao avéstico mogu- (ou möghu-). 
fornecia sacerdotes para os medos mas também para os persas, sendo talvez comparável à tribo israelita dos levitas. Segundo outra perspectiva ${ }^{12}$, esses mágoi seriam uma casta sacerdotal. Tinham funções hereditárias, e atuavam como conselheiros, sacerdotes/videntes e intérpretes de sonhos e eclipses.

Não se sabe quando a palavra $\mu$ óyoఢ foi assimilada em grego; um fragmento de Clemente de Alexandria (Protréptico, II.22.2) (13 $^{13}$ atribui a Heráclito uma invectiva profética contra os mágoi e outros grupos ${ }^{14}$ que se iniciam de maneira ímpia nos mistérios praticados pelos homens ${ }^{15}$. James R. Russell sugeriu que "na Grécia do $5^{\circ}$ e do $4^{\circ}$ séculos [a.C.] o termo mágos significava, primeiramente, um sacerdote persa, seja no sentido positivo ou no negativo", mas esse vocábulo "parece ter adquirido rapidamente a conotação alternativa ou adicional, decididamente negativa, de um prestidigitador, feiticeiro ou bruxo (a magician, wizard or sorcerer)" (Russell 2001 52). No Papiro de Derveni (2a metade do séc. V a.C.), ainda segundo Russell, o termo mágoi designa sacerdotes persas oficiantes do serviço zoroastriano da encenação ritual de "uma refeição em honra aos mortos, satūm” (RUSSELL 2001 54). Não pensa dessa forma Alberto Bernabé, para quem, no Papiro de Derveni,

A identidade dos $\mu$ óyol é um assunto controverso. Tsantsanoglou e Burkert insistem que os $\mu$ óyol são profissionais de origem estrangeira, talvez persa; Jourdan os vê como charlatães; Most e Betegh os vêem como sacerdotes órficos. Concordo com a explicação de Betegh de que, a despeito da origem persa da palavra, os

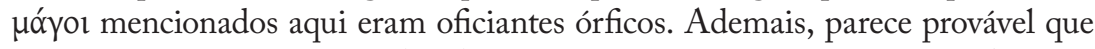
os magoi persas eram considerados peritos em atos rituais e que os oficiantes órficos eram correspondentemente comparados com eles (Bernabé 2008) ${ }^{16}$.

Heródoto (c. 484-425 a.C.) não mencionou Zoroastro nas suas Histórias, apesar de ter investigado com empenho as crenças e práticas religiosas dos povos iranianos, e do fato de que muitos dos ritos que ele descreve parecem zoroastrianos ${ }^{17}$. Xenofonte (c. 430-354 a.C.), mesmo tendo percorrido grande parte do território do império persa como mercenário do exército de Ciro (veteropersa Kürush) “o jovem” em 400 a.C., e escrito com riqueza de detalhes

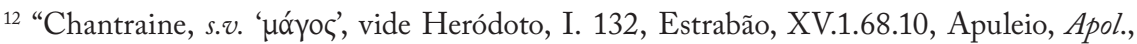

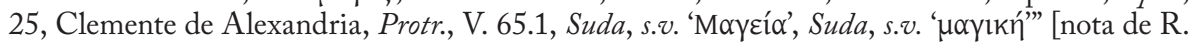
Martín Hernández (2006), El Orfismo y la Magía. Madri [tese], p. 56 n. 10 [disponível em <http:// pendientedemigracion.ucm.es/BUCM/tesis/fl/ucm-t29556.pdf >; acedido a 08/07/2014]).

${ }^{13}$ Heracl. Fr. 22B14 Diels-Kranz, Fr. 87 Marcovich.

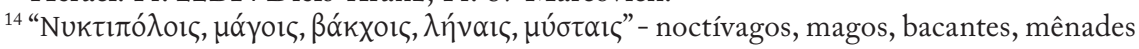
e mistagogos.

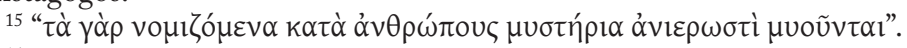

${ }^{16}$ De toda forma, "a conexão históricas entre os magos iranianos e a prática de 'magia' (que alguns eruditos quiseram negar) foi real, e muito significativa para os gregos” (Kinsley 1995 187).

${ }^{17}$ De Jong 1997339. 
sobre a educação do jovem príncipe e os costumes religiosos da corte, nada disse sobre Zoroastro. Ctésias de Cnido, um médico grego que foi refém na corte de Artaxerxes II de 404 até 398 ou 97 a.C. e que escreveu uma História dos Persas em 24 livros, dos quais só nos chegaram fragmentos, falou de Zoroastro (FGrH 688 F1f) como mago e quiçá (a pontuação é polêmica) rei da Báctria ${ }^{18}$, região onde sabe-se que o profeta viveu.

Durante o governo dos últimos reis medos no séc. VI a.C., em cuja corte os magos desempenhavam importante papel (Heródoto, Histórias, I.107), as reformas de Zaratustra levaram a uma modificação da antiga religião ${ }^{19}$, que envolvia alguma forma de mazdeísmo ${ }^{20} \mathrm{e}$ culto a Mitra. Antes da queda da Média, as cidades estado gregas da costa egeia podem ter conspirado com o rei medo Cyaxares (veteropersa Huvakbshtra) antes de 585 para derrotar a Lídia. Com a conquista da Média por Ciro II $^{21}$ (chamado "o grande" pelos gregos; filho de Cambises [Kambüjiza] I e neto de Kūrush I de Anshan) em 550 ou 549 a.C., alguns grupos de medos foram assimilados e favorecidos no império persa, enquanto outros possivelmente se deslocaram para o ocidente, levando formas peculiares de zoroastrismo e outros traços de sua cultura para aquelas regiões que estavam sob o domínio da Lídia (inclusive as cidades gregas da costa do Egeu), que pouco depois viria a cair sob o domínio de Ciro (entre 549 e 539 a.C.) ${ }^{22}$.

\section{Diferentes Retratos gregos de Zoroastro}

Os gregos construíram retratos de Zoroastro que podem ser distinguidos em três tipos: (I) Profeta ou mago; (II) Astrólogo; (III) Filósofo. Vejamos exemplos de cada um desses retratos.

${ }^{18}$ Em um fragmento de Cefálio (ano 120) preservado por Moisés de Corene (Khorenatsi), "Zoroastrem, mago Bactrianorum rege", ou (ed. William \& George Whiston) "Zaravaste mago, Bactrianorum rege" No texto preservado na versão armênia de Eusébio, Chron. 1.43 (ed. J. B. Aucher), "Zoroastri magi Bactrianorum regis".

${ }^{19}$ Conforme Mary Boyce "a existência dos Magos na Média, com suas próprias tradições e formas de culto, foi [ali] um obstáculo para a pregação de Zoroastro” [M. Boyce (1975), A History of Zoroastrianism, I: the early period. Leiden, Brill, p. 21].

${ }^{20}$ Entre 1967 e 1977 David Stronach escavou edificações em Tepe Nush-i Jan, c. 60km ao sul de Hamadã (antiga Ecbátana, capital dos medos), erguidas por volta de 750 a.C. e que parecem ter tido principalmente uso religioso. O templo central, apresentando piso com $11 \times 7 \mathrm{~m}$ e paredes com mais de $8 \mathrm{~m}$, apresentava um santuário triangular interior em cujo ângulo ocidental havia um altar em degraus, construído com tijolos e onde ardia uma chama. Esse é o templo mais antigo conhecido no Irã [D. Stronach (1985), "Tepe Nush-i Jan: The Median Settlement”. Em: Ilya Gershevitch (ed.), The Cambridge History of Iran. Cambridge: Cambridge University Press, vol. II, pp. 832-37].

${ }^{21}$ M. Waters (2010), Cyrus and the Medes. Em: J. Curtis \& St. John Simpson (eds.), The World of Achaemenid Persia: history, art and society in Iran and the ancient Near East (Proceedings of a conference at the British Museum, 29th September-1st October 2005). Londres/N. Iorque: I. B. Tauris, pp. 63-71; p. 68.

${ }^{22}$ M. Waters (2010), Cyrus and the Medes (op. cit.), p. 66. 
I) Zoroastro como profeta iraniano ou mago

Albert De Jong ${ }^{23}$ indicou cinco passagens principais de autores gregos nas quais foi transmitida alguma informação substancial sobre a religião iraniana: Heródoto, Histórias, I.131-32; Estrabão, Geografia, XV.3.13-15; Plutarco, Sobre Ísis e Osiris, 46-47; Diógenes Laércio, Vida e Obra dos Filósofos Ilustres, I.6-9, e Agatias, Histórias, II.23-5. Conforme Émile Benveniste ${ }^{24}$, Heródoto, Estrabão e Plutarco teriam descrito três tradições religiosas persas diferentes no espaço e no tempo - a antiga religião naturalista iraniana (Heródoto), o mazdaísmo “degenerado" (Estrabão) e o zurvanismo "puro" (Plutarco). Conforme De Jong (1997 2), as passagens de Heródoto e Agatias refletem tradições laicas, enquanto aquelas de Estrabão, Plutarco e D. Laércio "parecem refletir tradições sacerdotais zoroastrianas”. Ademais, Plutarco, Diógenes Laércio e Agatias fazem referência ao papel fundacional de Zoroastro:

a) Plutarco (c. 45-120) afirmou (De Iside et Osiride, 46, 369d-e), ao discutir teologias dualistas:

Alguns acreditam que existem dois deuses, como se fossem artesãos rivais (antitéchnoi), um o criador (dêmiourgos) das coisas boas e outro das coisas más. Outros chamam 'deus' ao melhor desses [deuses], e 'demônio' ao seu rival, como por exemplo Zoroastro o mago, que viveu, assim o registraram, 5.000 anos antes da guerra de Troia ${ }^{25}$. Ele costumava chamar um [o bom] de Horomázês e outro [o mau] de Areimánios $^{26}$ [Bidez —Cumont 1938: II 70-71 (Fr. D4)].

Conforme a continuação dessa mesma passagem, Zoroastro descreveu Horomazes como especialmente análogo à luz, enquanto Areimanios transparece escuridão e ignorância (skótôi kaì agnoíai) ${ }^{27}$.

b) Diógenes Laércio (fl. séc. III) apresenta "um panorama das obras perdidas de autoridades anteriores sobre a religião dos magos, que reflete um sumário do conhecimento grego convencional sobre a religião dos persas" (De Jong 1997: 2). Ele avalia positivamente a religião dos magos (absolvendo-os, por exemplo, da acusação de magia negra), e apresenta em favor disso uma fantasiosa etimologia grega para o nome o profeta iraniano (I.8): de acordo com Dínon de Cólofon

${ }^{23}$ De Jong 1997: 76-250.

${ }^{24}$ E. Benveniste (1929), La Religion Perse d'après les Principaux Historiens Grecs. Paris, Librairie Orientaliste Paul Geuthner.

${ }^{25}$ Essa é a cronologia de Hermodoro e de Hermipo (cf. Bidez - Cumont 1930: II 73 n. 4).

${ }^{26} \mathrm{Cf}$. ainda Plutarco, De anime procreatione in Timeo, 1026b.

27 Ahura-Mazdā (pálavi Ormazd) é simultaneamente rae e khva renangh, luz interior/ imanente e sua expressão exterior/ transcendente, donde a ausência de A.-Mazdā, personificada como Angra-Mainyu (pálavi Ahriman), ser identificada com as trevas e a indiscernibilidade, com a anagra temah, "escuridão infinita" (antítese da anagra raochâo, "luz infinita" - cf. o Avesta, fragmentos do Hadôkht Nask, caps. 2 e 3), expressão exterior dos maus pensamentos (dushmata), más palavras (dushūkhta) e más ações (dushuvarshta). 
e com o platonista Hermodoro de Siracusa, Zoroastro significaria astrothýtês, "adorador dos astros" (literalmente. "alguém que sacrifica às estrelas").

c) Agathias (c. 536-582), falando de certas "inovações" introduzidas por "Zoroastro, o filho de Horomasdes" na religião dos persas, afirmou:

Quando esse Zoroastro ou Zarades - pois ele é chamado por esses dois nomes - primeiro floresceu e estabeleceu suas leis é impossível descobrir com certeza. Os persas de hoje simplesmente dizem que ele nasceu no tempo de Hystaspes, sem maior esclarecimento, sendo esse assunto muito obscuro e sendo impossível dizer se esse Hystaspes foi o pai de Dario ou outra pessoa. Mas qualquer que tenha sido o tempo no qual ele floresceu, ele foi professor e guia deles nos ritos dos magos; ele substituiu seu culto original por doutrinas elaboradas e complexas [Bidez —Cumont 1938 II: 84 (Fr. D11); Cameron 1969-1970: 81 (texto) e 83 (trad.), com ligeiras modificações seg. De Jong 1997: 248-249].

Zoroastro de fato "estabeleceu as leis" do Mazdaísmo, e seu primeiro discípulo convertido, e depois seu protetor, foi um certo rei Hystaspes (mas não o pai de Dario).

A essas três passagens acima devemos acrescentar duas outras, ligadas ao nome de Platão (428 ou 427-348 ou 347):

1) No Primeiro Alcibiades (121e-122a) Sócrates diz: “(...) A sabedoria dos magos, de Zoroastro [filho espiritual] de Horomázon, é de fato o serviço (therapeía) dos deuses", proclamando ainda que Zoroastro instruiu os persas quanto a "como governar ( $t a ̀$ basilikâ)" segundo os preceitos da sabedoria, justiça, temperança e bravura [Jackson 1899: 231; Bidez - Cumont 1938: II 21-22 (Fr. B11)]. "Pelo contexto fica claro que a Pérsia é tida como uma civilização modelo, materialmente e culturalmente, onde são socialmente tornadas reais ideias que em Hellás tinham apenas alcançado o estágio de aspiração e articulação intelectual. E em particular a sabedoria Platônica é na Pérsia uma tradição antiga, praticada na educação do príncipe" (Voegelin 2000: 340).

2) Segundo Clemente de Alexandria, citado por Eusébio de Cesareia (Praep. Evang., XIII.13.30), Platão teria relatado, no décimo livro da República, que Zoroastro escreveu o seguinte nas linhas iniciais de sua obra Sobre a Natureza: "Eu, Zoroastro filho de Armenios [= Ahura-Māzda?], de raça panfiliana, eu que morri na guerra, escrevi essas coisas - aquilo que enquanto estive no inferno aprendi dos deuses" [Bidez - Cumont 1938: II 158 (Fr. O12) ${ }^{28}$. Zoroastro teria estado morto por 12 dias antes de retornar à vida ${ }^{29}$. Conforme Beck, em seu "mito de Er" (República, 614b-621b) Platão "pode ter se inspirado em uma estória iraniana anterior sobre

${ }^{28}$ Cf. Beck 1991: 518 e ss.; 528-530.

${ }^{29}$ Ainda segundo Clemente. O texto que se lê em Platão (República, 614b) é que um bravo guerreiro - Er, o filho de Armenios, da raça panfiliana - foi fatalmente golpeado numa batalha, e quando os corpos foram recolhidos dez dias depois, já em decomposição, aquele de Er estava intacto, e tendo sido trazido para casa, no momento do funeral no $12^{\circ}$ dia, quando estava para ser incinerado ele retornou à vida e relatou aquilo que havia visto no além. 
uma viagem feita por Zoroastro ou por algum outro mago para além do mundo" (Beck 2002). E como recorda Kingsley (1995: 204), "no famoso mito de Er ao final da República, Platão apresenta uma lista formal de cores correspondentes a cada um dos planetas [616e-617a] que concorda precisamente com as correspondências apresentadas em textos babilônios", e que foi assimilada pelos iranianos.

\section{II) ZoROASTRO COMO ASTRóLOGO}

No século VI, Lydos (Dos Meses, II.4 Wünsch ${ }^{30}$ ) atribuiu a criação da semana de sete dias - espelhada nos sete planetas - aos "Caldeus do círculo de Zoroastro e Hystaspes e aos egípcios” [Bidez - Cumont 1938: II 228 (Fr. O 85)], e a seção sobre "astronomia" na Suda observa que os babilônios, e com eles Ostanes, aprenderam o arranjo dos astros (astronomía) com Zoroastro [Suidas 1928-1938 alpha 4257; Bidez - Cumont 1938 II 18 (Fr. B7); II 269 (Fr. 4a)].

Os fragmentos remanescentes e os testemunhos existentes sobre os muitos escritos espúrios atribuídos a Zoroastro ${ }^{31}$ foram discutidos por Bidez e Cumont ${ }^{32}$ e extensamente analisados por Beck ${ }^{33}$, que forneceu ademais uma discussão sobre o Zoroastro dos hinos mágicos de Crisóstomo Dio Cocceiano e do tratado gnóstico Zostrianos, descoberto depois da publicação de Bidez e Cumont. Apesar de reconhecer que Bidez e Cumont lastrearam de forma bastante firme a interpretação do material pseudoepigráfico zoroastriano e forneceram valiosas contribuições para sua interpretação, Beck não concorda que esse material teria sido em grande parte obra de "magos helenizados" da diáspora iraniana na Anatólia (os "magosianos") e de que isso refletiria o sincretismo de uma autêntica tradição iraniana e zoroastriana (mesclada a uma tradução astrológica caldeia) com uma tradição grega. Ao invés disso, Beck propôs que esse material pseudoepigráfico "zoroastriano" é na verdade inteiramente grego ${ }^{34}$, e foi apenas cosmeticamente "iranizado", tendo sido atribuído por seus autores a "Zoroastro" com a intenção de lhe emprestar legitimidade e seriedade.

\section{III) ZOROAST RO COMO FILÓSOFo}

No afresco da "Escola de Atenas" (1510-1511), Rafael Sanzio pôs Zoroastro ao lado de Atena/a matemática, isto é, da sabedoria. A tradição que apoia essa associação é antiga: para o enciclopedista bizantino Suidas, Zoroastro não foi

\footnotetext{
Teubner.

${ }^{30}$ Ioannes Lydus (1898), Ioannis Laurentii Lydi Liber de mensibus, ed. R. Wünsch. Leipzig,

${ }^{31}$ Reproduzidos em Bidez - Cumont 1938: II 137-263.

32 Bidez - Cumont 1938: I 85-163.

${ }^{33}$ Beck 1991: 521-553.

${ }^{34}$ Beck 1991: 492-521.
} 
apenas um sábio, aquele a quem foram atribuídos 11 livros $^{35}$, mas teria sido, segundo Antístenes de Rhodes (c. 200 a.C.), um certo mago que "descobriu a sabedoria" (Suidas 1928-1938 zeta 159; alpha 2723). A edição de 2005 do Oxford Dictionary of Philosophy apresenta Zoroastro como o primeiro pensador na cronologia dos filósofos ${ }^{36}$, por ter sido ele o fundador da "mazdāyasna", expressão que pode ser traduzida como "culto (yasna) à sabedoria (mazdā)". Os sábios zoroastrianos teriam influenciado os gregos que depois usaram um termo similar, "amor à sabedoria" (philosophía), para designar a busca da verdade primeira ou suprema. De fato, James R. Russell ${ }^{37}$ (apud Rose 2000: 19) escreveu em relação a Zaratustra que "o mais importante princípio individual organizador da visão do Profeta (...) é a sabedoria (...). Ahura-Mazdā, Deus, é o Senhor da Sabedoria: dessa apercepção singular e avassaladora, precedida talvez por aquela contemplação da (Boa) Mente [(Vohu-)Manah] que sempre foi intrínseca ao pensamento religioso indo-iraniano, o Profeta pôde contemplar toda a vida em simetria".

Eugenio Ballabio (2009: 20) afirmou, apontando a "estupefaciente coincidência" da etimologia de Ahura-Mazdā com a ideia de Deus como princípio universal ao qual Platão chama de "mente" e "causa" ${ }^{38}$, que

Ahura equivale a "Senhor", Mazdā é composto de Manas ou "pensamento" e $d h a$, "pôr" ou "criar", o que conjuntamente significa "energia pensante e criativa”. Esse conceito contém seminalmente (in nuce) Platão e Aristóteles, que transformaram essa ideia de modo original. O primeiro afirma no Sofista que é impossível que "o ser perfeito seja privado de movimento, vida, alma e inteligência, e que não viva e não pense" (248e-249a). O arremate desse discurso ocorre no Timeu, no qual o "Demiurgo" é a causa do mundo que foi produzido por aquela bondade privada de inveja, que quer difundir e multiplicar o bem. O segundo, com a definição mais alta de Deus, que é aquela de "pensamento do pensamento" (...) (Ballabio 2009: 15).

Ainda conforme Ballabio (2009: 20), "é comum aos dois pensadores [Platão e Zaratustra] o tema do amor: o persa concebe o primeiro atributo de Deus como

35 "Quatro livros Sobre a Natureza, um Sobre Pedras Preciosas, um tratado Sobre Observações das Estrelas, cinco livros Sobre Escatologia” (Suidas 1928-1938 Zeta, 159).

${ }^{36}$ S. Blackburn, ed. (2005), The Oxford Dictionary of Philosophy, 2a ed. Oxford, Oxford University Press, s. v. "Philosophy", p. 405.

37 J. R. Russell (1996), "New Materials Towards the Life of the Prophet Zarathushtra". Journal of the Research and Historical Preservation Committee, 2, 1996 (Proceedings of the Second North American Gatha Conference [Houston, Texas, 31/08-02/09/1996], ed. Pallan R. Ichaporia, Sarosh J. H. Manekshaw. Womelsdorf: FEZANA [Federation of Zoroastrian Federations of North America]), seção 18, p. 209.

${ }^{38}$ Ballabio remete a D. Laércio, III.69. 
Vohu Manah ou bom pensamento ${ }^{39}$, enquanto a temática do eros tem um grande peso no grego $0^{40 "}$.

A narrativa de Crisóstomo Dio Cocceiano (Dîon Chrysóstomos; c. 40-c. 115) exemplifica a percepção grega de Zoroastro como filósofo, sendo-lhe muito favorável (Orationes, 36.40):

Os persas dizem que Zoroastro, devido a uma paixão pela sabedoria e justiça, afastou-se dos seus concidadãos e foi morar sozinho numa certa montanha, e que logo depois a montanha pegou fogo, a partir de uma poderosa chama descendo do céu, e que queimava incessantemente. Então o rei e os mais distintos dentre os persas se aproximaram com o propósito de orar ao deus, e Zoroastro apareceu ileso saindo do fogo, e mostrando-se cortês em relação a eles, admoestou-os a terem bom ânimo e oferecerem certos sacrifícios em reconhecimento ao fato do deus ter chegado àquele lugar. E depois disso, afirmam eles, Zoroastro não se associou com todos os persas, mas apenas com aqueles melhor dotados em relação à verdade e mais aptos a entender o deus, homens a quem os persas denominaram magos, ou seja, pessoas que sabem como servir à divindade. Essa denominação não se assemelha àquela dada pelos gregos, que em sua ignorância usam o termo para denotar feiticeiros [Jackson 1899 236-237; Bidez - Cumont 1938 II 28-29 (Fr. B 17); Dio Chrysostom 1940456 (grego) e 457 (trad. H. Lamar Crosby)].

\section{IIIA) Zoroastro E A HERANÇA da ACAdEMia PLATÔNICA}

Conforme Beck, "diz-se com bastante credibilidade que Platão teve conexões com os magos [iranianos]” (Beck, 2002) ${ }^{41}$. De acordo com uma antiga tradição, Platão teve muita vontade de visitar o Oriente e estudar com os magos, mas desistiu disso por conta das guerras [contra os Persas] na Ásia (Dióg. Laércio, III.7). Outra tradição fala que, por conta dessas guerras, Platão viajou para a Fenícia e lá teria sido instruído pelos magos (Olimpiodoro, In Alcibiadem, 2.138-143) ${ }^{42}$.

${ }^{39}$ Conforme Phillip Sidney Horky, "mesmo que não esteja explicitamente correlacionado, o princípio da Boa Mente (Vohu Manah) poderia ser altamente significativo para a interpretação da porção cosmológica do Papiro de Derveni (grosseiramente, cols. xiii-xxi)" [P. S. Horky (2009), "Persian Cosmos and Greek Philosophy: Plato's Associates and the Zoroastrian Magoi”. Oxford Studies in Ancient Philosophy, 37: 47-103; cf. p. 66 n. 70].

${ }^{40}$ Ballabio remete particularmente ao Simpósio, ao Fedro e ao Timeu.

${ }^{41}$ Beck remete a Kingsley 1995; cf. pp. 199-207.

${ }^{42}$ A viagem de Platão à Fenícia, onde teria sido iniciado nos ensinamentos de Zoroastro, também é relatada - embora sem menção à guerra que teria impedido a viagem à Pérsia - pelo autor anônimo da Vida de Platão (4.10-14) editada por L. G. Westerink, ed. (1962), Prolegomena Philosophiae Platonicae/Anonymous Prolegomena to Platonic Philosophy, sometimes wrongly attributed to Olympiodorus (grego/inglês). Amsterdam, North-Holland Publishing Company [cf. A. S. Riginos (1976), Platonica: The Anecdotes concerning the Life and Works of Plato (Columbia Studies in the Classical Tradition, 3). Leiden: E. J. Brill, p. 66; Jacoby Bollansée - Engels - Schepens -Theys 1998 262]. 
Uma incontestável ligação entre os iranianos e Platão aparece em fontes antigas que tratam de complexas relações cronológicas. Conforme Jenny Rose,

Segundo Plínio [Nat. Hist., 30.2], tanto Eudoxo [Fr. 342 Lasserre] quanto Aristóteles [Fr. 34 Valentin Rose] relataram que Zoroastro viveu 6.000 anos [= metade de um "grande ano" iraniano $]^{43}$ antes da morte de Platão ${ }^{44}$. A implicação dessa data (...) é que os ensinamentos de Zoroastro de certa forma se cumprem com Platão $0^{45}$. Platão representa, portanto, o começo de um novo ciclo, e seu predecessor Pitágoras ${ }^{46}$ age como um precursor desse período transicional (Rose 200049 [c/ inserções nossas]).

Para Kingsley (1995: 192), “a colocação de Zoroastro no início desse período mundial [de 6.000 anos] não apresenta qualquer problema: não se trata de uma data a ser factualmente analisada, mas que deve ser entendida como um reflexo da percepção de Zoroastro e de sua religião como a realidade determinante do mundo no qual vivemos". Não se há de ver no relato de que Zoroastro teria vivido 6.000 anos antes de Platão obrigatoriamente uma sugestão de que na Academia ou entre alguns persas estabelecidos em Atenas se acreditava que Platão seria uma encarnação de Zoroastro ${ }^{47}$, embora isso não possa ser simplesmente descartado - aquilo que Eudoxo e Aristóteles disseram quanto a esse intervalo de 6.000 anos de fato pode ter significado,

43 "Sabemos por Teompompo [FGrH 115 F65], que quiçá aprendeu isso com Eudoxo, que a geração deste e de Aristóteles tinha conhecimento do grande ciclo da religião iraniana e do drama universal da luta entre Ormuzd e Ahriman" (Jaeger 1946 157). É também de 6.000 anos o período transcorrido entre a criação da alma (fravashi) de Zaratustra e sua aparição na Terra [M. L. West (2013), "The Date of Zoroaster". Em: Hellenica: Volume III: Philosophy, Music and Metre, Literary Byways, Varia, pp. 89-109; cf. p. 96]. Sobre os ciclos iranianos de 12.000 anos e suas subdivisões cf. Aristotele 196387 e E. Fernandes (2012), "As origens iranianas do milenarismo”. Mirabilia: Revista Eletrônica de História Antiga e Medieval, 14: 9-34, p. 15 e ss., e veja-se ainda Kingsley 1995: 192; Voegelin 2000 338-340.

${ }^{44}$ Sobre esse ponto em particular cf. Kingsley 1995: 193-194.

45 “Como os acadêmicos tem frequentemente estimado, a datação de Zoroastro em seis mil anos antes de Platão implica numa percepção de algum laço especial entre eles: o ensinamento de Platão era visto como se, de alguma forma, cumprisse e completasse aquele de Zoroastro (isso foi primeiramente indicado por W. Jaeger [Aristoteles..., 1923]) e E. Benveniste [La Religion Perse d'après les Principaux Historiens Grecs, 1929, pp. 14-21], de forma independente entre si)" (Kingsley 1995: 195 c/ n. 146 [parte]).

${ }_{46}$ Porfírio (Vita Pythagore, 23, 12) e Jâmblico (De vita pythagorica, XIX, 154) falam da instrução de Pitágoras pelo caldeu Zaratas (uma corruptela de Zaratustra), e há muitas referências interessantes à conexão entre Pitágoras e Zoroastro/Zaratustra, apresentando o primeiro como discípulo do segundo (cf. Hipólito, Refutação das Heresias, I, 2.12 [citando Diodoro, o eritreu, e Aristóxeno]; Clemente de Alexandria, Stromata, I, 15, 69; Plutarco, De anime procreatione in Timao, 1012E, e Apuleio, Florida, 15 - passagens citadas em Bidez Cumont 1938: II).

${ }^{47}$ Cf. Bidez - Cumont 1938: I 14; Dillon 2003: 199. 
segundo a concepção iraniana, que Platão é uma reencarnação de Zaratustra, isto é, que ele é o redentor, com o qual o "grande ano" tem seu cumprimento e sua conclusão. Isso significa nessa época que, segundo a doutrina da Academia, 6.000 anos antes teria ocorrido uma catástrofe; isso corresponde, portanto, àquela [data] que é paralela com a primeira catástrofe iraniana, no curso da qual Zaratustra foi enviado ao mundo, e isso coincide somente com a catástrofe da Atlântida, que em seguida [ao influxo iraniano na Academia] vem datada de 6.000 anos antes de Platão (Brandenstein 1951a: 84).

\section{De fato, como apontou Mario Untersteiner,}

é de se notar como a concepção iraniana apresenta um paralelo exato em Platão, para o qual já 9.000 anos antes de então os deuses dominavam desde um tempo imenso e, propriamente, 9.000 anos antes eles dividiram a terra entre si (Timeu, 23e), ou seja, somente então a terra foi materializada e tornada habitável, depois do que começou um estado paradisíaco (...) (Aristotele 1963: 86).

Platão sorveu da doutrina cósmica iraniana segundo a qual "o mundo materializou-se 9.000 anos atrás e então houve um estado paradisíaco. Segundo a concepção iraniana, passaram-se 3.000 anos até o desastre e aniquilação do primeiro mundo. Platão, contudo, não se expressou de forma tão precisa. Ele fala de muitas idades humanas em estado paradisíaco, seguidas por uma deterioração (Verschlechterung) gradual que eventualmente levou à destruição (Untergang)" (Brandenstein 1951b: 9).

Autores como Éric Pirart sugerem que entre os iranianos existiu uma crença de que cada época fulcral teve o seu Zaratustra, "o Zoroastro em vigor", "o Zoroastro do momento" (Pirart 2010: 11-12), o que indicaria, mais que uma crença reencarnacionista, que após o primeiro indivíduo conhecido por esse nome houve outros que tiveram "Zaratustra" como título honorífico (como quiçá teria sido o caso do "Zaratas" que foi instrutor de Pitágoras) ${ }^{48}$ indicador da figura mais importante de cada ciclo histórico. John Dillon, contudo, admitiu a possibilidade de que já na época de Hermodoro de Siracusa (discípulo de Platão até a morte deste) os gregos haviam começado a ver Zoroastro como "um antecedente remoto de Platão" (Dillon 2003: 199) ${ }^{49}$.

${ }^{48}$ Plínio (Naturalis Historia, 30.3 e 8) disse que houve dois Zoroastros - um primeiro, que viveu milhares de anos antes, e um segundo que viveu pouco antes do mago Ostanes, que acompanhou Xerxes em sua invasão da Grécia.

${ }^{49}$ Conforme Hermodoro, "sobre [a data d'] os magos, começando com Zoroastro o persa, transcorreram 5.000 anos até a captura de Troia” (D. Laércio, I.2). Hermipo (Fr. 2 Wehrli) situou Zoroastro 5.000 anos antes da Guerra de Troia. 
Peter Kingsley ${ }^{50}$ sugeriu que a ideia de que os ensinamentos de Zoroastro se cumprem com Platão pode ter sido elaborada em Atenas por magos visitantes ou ali estabelecidos. Reportando-se a Phillipos de Opus, autor do Epinomis conforme a tradição preservada por D. Laércio (III.37), Filodemo de Gadara falou no Academicorum Philosophorum Index Herculanensis ${ }^{51}$ - que no máximo pertence ao século I -, da presença de um "caldeu" junto ao leito de morte de Platão - provavelmente aquele mesmo "Chaldaios" ("caldeu”) que, segundo Phillipos, "era membro regular da escola" (Jaeger 1947 154). O autor anônimo de uma Vida de Platão falou (60.20-22) de magos persas que chegaram a Atenas para aprender com Platão e "participar de sua filosofia" 52. Sêneca (Epistularum libri XX, 58.31) relatou a presença de alguns "magos" em Atenas quando da morte de Platão, fazendo sacrifícios junto ao corpo deste ${ }^{53}$. Já conforme Diógenes Laércio (III.25), "no livro I dos Apomnêmoneumata [Memorabilia] de

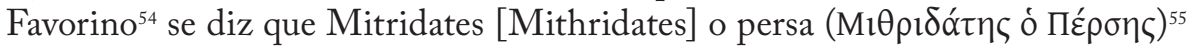
pôs na Academia uma estátua de Platão com a seguinte inscrição: 'Mitradates [Mithradates] o persa, filho de Rhodobates [R(h)oontopates; Orontobates] ${ }^{56}$,

${ }^{50}$ Kingsley 1995: 196-198.

51 S. Mekler, ed. (1902), Academicorum Philosophorum Index Herculanensis. Berlim: Weidmann [repr. 1958], III, p. 13, 36-41; Filodemo (1991), Storia dei Filosofi. Platone e I’Academia (PHerc. 1021 e 184), ed. Tiziano Dorandi, Nápoles: Bibliopolis, II, 35-41.

${ }^{52}$ Kingsley 1995 196, remetendo a L. G. Westerink, ed. (1962), Prolegomena Philosophiae Platonicae/Anonymous Prolegomena to Platonic Philosophy, sometimes wrongly attributed to Olympiodorus (grego/inglês). Amsterdam, North-Holland Publishing Company, p. 15.

${ }^{53}$ Kingsley 1995: 196. Kingsley recorda ainda (1995: 198) que "pouca dúvida pode existir quanto a que os magos algumas vezes empregaram sua aparente vontade de aprender como um disfarce para esconder sua intenção mais profunda de influenciar e ensinar",

${ }^{54}$ Favorino de Arles, c. 80-160 d.C.; 'A

${ }^{55} \mathrm{Na}$ edição de Hicks esse nome aparece grafado nessa passagem como "Mithradates" duas vezes, ao contrário da edição de H. S. Long (Oxford, 1964) que, acompanhando a maioria dos manuscritos, grafa "Mithridates" (forma mais grecizada, mais moderna?) e depois "Mithradates" (forma mais próxima do persa).

${ }^{56}$ A história registra um Mitradates (veteropersa Mithradāta, "Dádiva de Mitra") da Frígialde Quios (sátrapa da Capadócia e da Licaônia segundo Xenofonte, e morto antes de 362 a.C.), pai [segundo supôs Walther Judeich (1895), s. v. "Ariobarzanes". Em: A. Pauly, G. Wissowa (eds.), Realencyclopädie der classischen Altertumswissenschaft, 2 (3): 832-833; cf. col. 832 n¹, suposição essa refutada por Brian C. McGing (1986), "The Kings of Pontus: Some Problems of Identity and Date". Rheinisches Museum, 129: 248-259] ou irmão de Ariobarzanes I da Frígia/de Quios (415-362 a.C.) (veteropersa *Äriyabrzânna [Äriyabrdhāna; Äriyabrdhāna]), "Exaltação dos árias" [seg. M. A. Dandamayev, A. Sh. Shahbazi; P. Lecoq, "Ariobarzanes” (1986; 2011). Encyclopaedia Iranica. Nova Iorque, Iranica on line. Em: <http://www.iranicaonline. org/articles/ariobarzanes-greek-form-of-old-iranian-proper-name-arya-brzana>; acedido a 03/04/2014] e tio ou avô de Orontobates da Frígia/de Quios (385-após 316 a.C.), sátrapa da Cária (nos anos 330 a.C.), irmão de Mitradates II da Frígia/de Quios (c. 386-302 a.C.), vassalo de Antígono e filho de Ariobarzanes I (e depois sucessor de Ariobarzanes II). Ariobarzanes I e três dos seus filhos receberam cidadania ateniense [em 368 a.C.], segundo Demóstenes (Contra Aristocrates, 23.141 e 23.202), por terem assegurado a Atenas o direito ao Quersoneso (entregando-1he Sestos e Crithote). Esse Orontobates [grego Orontobátês; iraniano *Ravanta- 
dedicou às musas esta imagem de Platão feita por Silanião"'57 [D. Laërtius 1972 I 300 (grego) e 301 (trad.)]. Acredito que esse Mitridates, que pode ter sido "membro regular da escola" de Platão ${ }^{58}$, foi filho do último sátrapa persa da Cária, tendo provavelmente recebido a cidadania ateniense junto com seu pai [vide nota 56]. A autodenominação de "o persa", junto com o emprego do nome mais correto Mitradates, podem ser evidências de uma declaração fática, bem como de uma nostalgia de origem. Também não se pode descartar a hipótese de que o uso do epíteto Pérsês seja uma resposta irônica de Mitradates a alguém que estivesse a chamá-lo indevidamente de Chaldaios $^{59}$, o que não seria incomum à época. Segundo Bidez e Cumont, "foi provavelmente através de Eudoxo [de Cnido; c. 408-355 a.C.] que mais de uma doutrina oriental chegou a Platão e à sua escola"60 (Bidez - Cumont 1938: I 12). Conforme Plínio (Nat. Hist., 30.2), "Eudoxo empenhou-se em mostrar que [a arte da magia] era a mais ilustre e

pāta, veteropersa *Arvant(d)apāta (Aurandabad); avéstico Aurvant-pāta; Aroantopata (Orontopates), "Protegido por Aurvant (Orontes)"] deve ser o pai do Mitradates, que foi o discípulo de Platão, e que quiçá não teria sido o sátrapa. Erich Preuner (1903), "Griechische Siegerlisten". Mitteilungen der kaiserlich deutschen archäologischen Instituts, Athenische Abteilung, 28: 338-382 (cf. 349-350), identificou nosso Mitradates filho de Orontobates como Mitradates I de Quios, enquanto Stephen G. Miller (2009), The Berkeley Plato: from neglected relic to ancient treasure. An archaeological detective story. Berkeley/Los Angeles/Londres, University of California Press, p. 34 n. 78, identificou nosso Mitradates filho de Orontobates com "Mitradates do Ponto, que morreu em 363 a.C." (na verdade, Mitradates I do Ponto viveu entre 349-266 a.C.; quem morreu por volta de 363 a.C. foi Mitradates de Quios) [cf. ainda Brian C. McGing (1986), "The Kings of Pontus: Some Problems of Identity and Date" (op. cit.)]. Théodore Reinach (1895), Mithridates Eupator, König von Pontos. Leipzig: Teubner [reimpr. Hildesheim: Georg Olms, 1975], p. 2 n. 3, supôs que o Mitradates discípulo de Platão teria sido filho de "Norondabátês" (Ctésias, FGrH 688 F13), um dos conspiradores que favoreceram a ascensão de Dario ao poder em 522 a.C., mas as datas são incompatíveis.

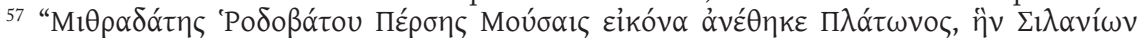

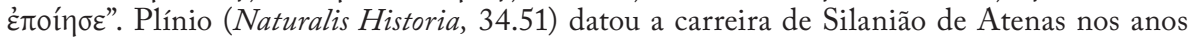
328-325 a.C.

${ }^{58}$ Ernst Curtius admitiu, pelo menos, que ele pode ter sido contemporâneo de Platão [E. Curtius (2011), The History of Greece, trad. A. W. Ward, vol. 5 (ed. alemã: 1867; 1ª ed. inglesa 1873). N. Iorque, Cambridge University Press, p. 208 n.].

${ }^{59}$ Konrad Gaiser e Heinrich Dörrie sugeriram que Mithradates foi o "caldeu" que esteve junto ao leito de morte de Platão [K. Gaiser (1988), Philodems Academica: Die Berichte über Platon und die Alte Akademie in zwei herkulanensischen Papyri (Supplementum Platonicum, 1). Stuttgart/Bad Cannstatt, Frommann-Holzboog, pp. 421-22 e 434-36; H. Dörrie (1990), Der hellenistische Rahmen des kaiserzeitlichen Platonismus: Text, Ubersetzung, Kommentar. ed. M. Baltes, A. Dörrie, F. Mann (Der Platonismus in der Antike: Grundlagen, System, Entwicklung, 2. Bausteine 36-72). Stuttgart-Bad Cannstatt, pp. 421-22].

${ }^{60}$ Eudoxo atribuiu o verdadeiro mérito de Zoroastro à sua moral, deduzida de seu dualismo (cf. Diógenes Laércio, I.8). "A influência de Eudoxo sobre Platão e sobre o Aristóteles do Perì Philosophias é posta à luz por Bignone (1936), l'Aristotele Perduto [e la formazione di Epicuro. Florença], vol. II, p. 84" (Bidez - Cumont 1938 I 12 n. 2 [trecho]). No tempo de Eudoxo, "a Academia era o centro de um interesse muito forte pelo Oriente (...), e esse interesse tem uma grande significação, de modo algum suficientemente reconhecida" (Jaeger 1946 154; cf Aristotele 1963 82-83). 
benéfica de todas as escolas de sabedoria" ${ }^{61}$. Contudo, a possibilidade de que o persa Mitradates tenha levado doutrinas iranianas à Academia não pode ser descartada. Para Bidez e Cumont,

O caráter iraniano do mito de Er não é mais contestável ${ }^{62}$, e também há muito tempo as contribuições do dualismo persa ${ }^{63}$ aos últimos diálogos do mestre vêm sendo assinaladas. Esse dualismo pode haver contribuído para dar - tanto nas Leis [X, 896e-897] quanto no Epinomis ("Apêndice às Leis" [986e; 987b; 987d-988a]) - sua forma particular à ideia de uma alma ruim do mundo. Precedentemente, com efeito, em Platão a causa do mal havia sido apresentada como uma espécie de inércia, de insuficiência ou de inaptidão, ou seja, como uma privação, e não como uma alma, princípio positivo de ação ${ }^{64}$, ao que se pode acrescentar que a daimonologia admitida pelo autor do Epinomis - assim como aquela de Xenócrates ${ }^{65}$ - não pode ser satisfatoriamente explicada sem a intervenção de crenças avizinhadas daquelas dos $\operatorname{Magos}^{66}$ (Bidez - Cumont 1938: I 12).

Não se discute hoje a informação de que, através de Eudoxo, "a primeira geração platônica foi impregnada de influências persas” (Puech 1952: 84) - e lemos na obra de Bidez - Cumont (1938: I 93-94) que "com efeito, para os gregos ${ }^{67}$, Zoroastro e seus discípulos são sophoi por excelência, se bem que [o vocábulo] 'mago' era visto como um sinônimo de ‘sábio': tal era, assegurava-se, o significado dessa palavra entre os persas. (...) Foi provavelmente Aristóteles, no seu Perì Philosophias, quem primeiro reconheceu aos magos a 'sabedoria', sophia"68.

61 "Eudoxus (...) inter sapientiae sectas clarissimam utilissimamque [artem magicam] eam intellegi voluit". Como recorda Kingsley (1995 189), os magos foram "venenosamente atacados" por Plínio (Nat. Hist., 30.2.8) "por contaminarem aos gregos e, como sugere o contexto, particularmente aos filósofos gregos mais antigos (early)".

62 "Cf. Bidez (1933), Bulletins de l'Academie Royale de Belgique, Cl. des Lettres, p. 273 e ss., e 1935, p. 257 e ss." (Bidez - Cumont 1938: I 12 n. 2 [trecho]).

${ }^{63} \mathrm{O}$ primeiro registro histórico importante do dualismo iraniano é aquele de Teopompo, FGrH 115 F65 Jacoby; Bidez - Cumont 1938: II 72 (Fr. D4), I.3-10), preservado por Plutarco junto com outras citações (De Iside et Osiride, 45-47, 369d-370c; cf. Bidez - Cumont 1938: II 71-72 (Fr. D4)].

${ }_{64}$ "Cf. Bidez, ibid., e Cumont, Religions Orientales, 4a ed., p. 278, n. 47" (Bidez - Cumont 1938: I 12 n. 3).

${ }^{65}$ E também a daimonologia de Porfírio no De Abstinentia, II, 37-43 (Bidez - Cumont 1938: I 178-179).

66 "Bidez, (1933), Bulletins de l'Academie Royale de Belgique, Cl. des Lettres, p. 280, n. 54, e Andrés, Realenc., Supl., t. III, p. 296" (Bidez-Cumont 1938: I 12 n. 4).

${ }^{67}$ Esses autores citam, em seu apoio, passagens de Eudoxo, Platão, Hesíquio, e do pseudo-João Crisóstomo, aduzindo o testemunho não-grego do livro de Daniel (2: 2 e 18, onde os magos e os caldeus são chamados de "sophoi babilónos") e da Hagadá judaica (cf. Bidez - Cumont 1938: I 93 n. 3).

68 “Cf. W. Jaeger (1938), The Journal of Religion, XVIII, p. 129: 'In the dialogue On Philosophy... Aristotle combines both Greek philosophy and oriental religious systems like that of 
Para Enrico Berti, "parece que Aristóteles, no livro I do Perì Philosophias, se ocupava dos magos, porquanto esses constituíam uma das mais antigas - talvez a primeira - secta sapientiae, ou seja, categoria daqueles que praticavam a sophia". "É verossímil que no Perì Philosophias Aristóteles se interessasse (...) pelos magos enquanto aqueles primeiros e mais ilustres buscadores que tentaram constituir uma forma de sophía" (Berti 1997: 267 e 268). Já segundo Bertrand Dumoulin,

Parece que Aristóteles buscou na doutrina dos magos um precedente para sua própria doutrina - que ele sempre partilhará com Platão - da anterioridade [e superioridade] do Perfeito sobre o Imperfeito [Metaf., N, 1091b9-12]. Essa afirmação da superioridade do bom princípio sobre o mau não exclui por si só que Aristóteles tenha podido tomar qualquer coisa do dualismo mazdeísta. Essa questão havia sido posta por Heráclito e Empédocles [Purificaçôes, Fr. B 134 Diels-Kranz], e também foi posta por Platão [particularmente em Leis, 896d e ss.] (Dumoulin 1981: 98-99).

Mircea Eliade sugeriu que Platão parece ter conhecido a ideia iraniana de que "o propósito das catástrofes cósmicas [Político, 269c e ss.] seria a purificação da raça humana (Timeu, 22d)" (Eliade 1992 107), e Estiphan Panoussi propôs que a influência de Zoroastro sobre Platão foi bastante significativa:

Os atenienses condenaram Sócrates porque ele propagava o culto dos deuses estrangeiros. De que deuses se tratava? No dizer de Heródoto, os persas não haviam concebido seu Deus à maneira antropomórfica dos gregos; por outra parte, Platão não hesita em criticar a concepção grega dos deuses (Rep., II, 379b-c - 396). Não teria isso se dado sob a influência de Zoroastro? Não recebeu Platão de Zoroastro o dualismo do espírito e da matéria? ${ }^{69}$ Ele recorre à causalidade do demiurgo como a um princípio inteligente que quer o bem, e a uma causalidade cega para explicar a presença do mal no mundo: isso lembra evidentemente o dualismo iraniano (Panoussi 1968: 240).

Werner Jaeger pensava que Platão foi inicialmente atraído por Zaratustra "por causa da fase matemática na qual havia acabado de entrar sua teoria das Ideias, e por causa do dualismo intensificado nela envolto", acreditando também

the Zoroastrians, the Magi, under the common denomination of wisdom (sophía), which sometimes designates in Aristotle the metaphysical knowledge of the highest principles, or theology" (Bidez Cumont 1938: I 248, “addictions et corrections" à n. 1 da p. 94).

${ }^{69}$ Platão, talvez influenciado pelo dualismo iraniano, adotou no Fedro (250C) a crença órfica de que o corpo (a matéria) é o túmulo da alma/do espírito. "Como primeiros precursores do dualismo platônico, Aristóteles (Metafís., N, 4, 1091b8) menciona Ferécides na Grécia e os Magi na Ásia” (Jaeger 1946: 156-157 c/ n. 22). 
que as duas almas opostas (a má e a boa) nas Leis, $896 \mathrm{e}^{70}$, seriam um tributo aos ensinamentos do profeta iraniano (Jaeger 1946 155). Para o classicista alemão, a partir daí a Academia permaneceu tão "vivamente interessada em Zaratustra e no ensinamento dos magi” que, no tempo em que Aristóteles estava compondo seu Perì Philosophias ${ }^{71}$,

o entusiasmo da Academia por Zaratustra chegou a um nível de intoxicação semelhante àquele da redescoberta da filosofia indiana através de Schopenhauer. Isso levou a autoconsciência histórica da Escola a pensar que a doutrina platônica do Bem como um princípio universal divino ${ }^{72}$ havia sido revelada à humanidade do Leste por um profeta oriental milhares de anos antes (Jaeger 1946: 157).

Aristóteles (Metafísica, 1091b10) atribuiu aos magos uma das primeiras concepções do dualismo. Ele disse ainda, no primeiro livro do Perì Philosophías (Fr. 6 Valentin Rose), que os magos, que são mais antigos que os egípcios, acreditavam em "dois princípios existentes por si mesmos, o espírito (daimôn) bom e o espírito mau, um chamado Zeus ou Horomásdês e o outro Hades ou Areimánios"73 (DL, I.8) [Bidez - Cumont 1938 II 67 (Fr. D2) 74; Aristotele 1963 6 (grego) e 7 (trad.); D. Laërtius 1972 I 10 (grego) e 11 (trad.)]. Bidez e Cumont dizem ainda que

Entre os fragmentos do Perì Philosophías, que por muito tempo, antes da voga da Metafísica, teve para o desenvolvimento dos sistemas filosóficos da Grécia uma importância que vem sendo descoberta pouco a pouco, encontramos - sobre a harmonia do mundo concebido como um grande templo, sobre o grande ano e sobre as reaparições periódicas das mesmas opiniões no pensamento humano ${ }^{75}$ - restos de teorias aparentadas ao mesmo tempo àquelas

${ }^{70}$ Reprod. em Jaeger 1946: 155 n. 18. Para uma discussão relativa às implicações das passagens relevantes das Leis cf. Fien Deceuninck (2012), Plato: dualisme en de Oriënt. De verhouding van Wetten $X .896 e$ - 897 tot het Perzisch dualism [dissertação]. Universiteit Gent, Faculteit Letteren en Wijsbegeerte.

${ }^{71}$ Cf. o Fr. 6, em Plutarco, De Iside et Osiride, 370e.

72 "Desde os teólogos 'mistos', aqueles que não dizem tudo em forma mítica, tal como Ferécides e alguns dos outros, e também os magos, denominam o primeiro criador a melhor coisa" (Aristóteles, Metafís. 1091b8).

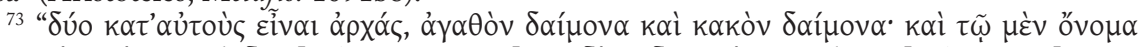

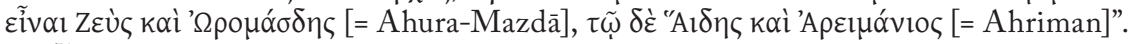

${ }^{74}$ Cf. Bidez - Cumont 1938: I 59 n. 3.

75 "Ideia apresentada no Perì Philosophias, de que todas as verdades humanas têm seus ciclos naturais e necessários. (...) Zaratustra e Platão são evidentemente duas importantes etapas na viagem do mundo rumo à sua meta, o triunfo do Bem. (...) Foi Aristóteles quem, levado por sua doutrina do retorno periódico de todo conhecimento humano, vinculou especificamente a cifra de 6.000 anos [de intervalo entre Zaratustra e Platão] ao retorno do dualismo" (Jaeger 1946: 156,158 e 160). 
do Epinomis [986e; 987b; 987d-988a] e às crenças dos Magos do círculo de Xerxes $^{76}$. Ademais - e conjuntamente, talvez ${ }^{77}$ - nessa mesma produção de seu primeiro ensinamento, ainda bastante fiel ao espírito da escola platônica, Aristóteles parece haver admitido que a fundação da Academia teria passado por um renascimento do espírito de Zoroastro. Pelo menos, retomando a ficção do passado mítico onde - segundo o testemunho de seu condiscípulo [Hermodoro de Siracusa] - o Oriente havia reportado a existência do profeta, ele havia julgado bom mencionar a prodigiosa cronologia que colocava entre os dois representantes de uma mesma sabedoria - Zoroastro e depois Platão - um período de seis mil anos (Bidez - Cumont 1938: I 16 [com inserções nossas]).

\section{Para Eric Voegelin,}

$\mathrm{Na}$ consciência epocal de Aristóteles, Hellás alcançou o nível espiritual na cena mundial através de Platão. Como uma potência espiritual agora ela era igual às civilizações orientais mais antigas. (...) As fontes fragmentárias não revelam qual função precisa Aristóteles teria reservado a Zoroastro ou Platão no drama mundial; tudo o que sabemos é que obviamente ele os considerou como figuras importantes na luta pela vitória do Bem no mundo e que ele aceitou a ideia iraniana das épocas nessa luta, espaçadas por múltiplos de três mil anos (Voegelin 2000: 339).

Plutarco, que achava que uma religião dualista era a mais plausível (De Iside et Osiride, 45-47, 369d-370c), apontou Zoroastro como o melhor exemplo de alguém que ensinou essa crença ${ }^{78}$. No século III, o neoplatonista Porfírio de Tiro (c. 234 - c. 305) apresentou um fantasioso retrato de Zoroastro como fundador do culto a Mitra (De antro nympharum, 6, 8-9). Como Zoroastro foi tomado pelos gregos como sendo o fundador da religião persa, e já que o culto de Mitra era o exemplo mais difundido das "práticas mistéricas dos persas", pareceu natural a muitas pessoas no mundo grego, helenístico e romano acreditar que o mitraísmo teria sido fundado por Zoroastro:

76 "Cf. o Fr. B 2, p. 9, e Aristotelis dialogorum fragmenta, ed. R. Walzer, 1934: 70 s. (Fr. 8); cf. a p. 65 (Fr. 19) e 73 (Fr. 12); cf. também a Metafísica [N4] 1091b855; Bignone, L'Aristotele Perduto, t. II, p. 84, p. 342" (Bidez - Cumont 1938: I 16 n. 2).

77 "Os textos de que dispomos são muito pouco explicativos para fazer ver sob qual forma Aristóteles apresentou as reaparições periódicas das mesmas doutrinas no curso da história” (Bidez - Cumont 1938: I 16 n. 3).

${ }^{78}$ Cf. J. Hani (1964), "Plutarque en face du dualisme iranien”. Revue des Études Grecques, 77: 489-525, e De Jong 1997: 157-204. 
Euboulos $^{79}$ nos diz que Zoroastro foi o primeiro a dedicar uma caverna natural em honra a Mitra, o criador e pai de tudo; ela estava localizada nas montanhas próximas à Pérsia, e tinha flores e fontes. Essa caverna era para ele a imagem do Cosmos que Mitra criou, e as coisas que a caverna continha ofereciam a ele, pelo seu arranjo proporcional, símbolos dos [diversos] elementos e climas do Cosmos. Depois de Zoroastro, outros adotaram o costume de realizar seus ritos de iniciação em cavernas e grutas, sejam elas naturais ou artificiais [Bidez - Cumont 1938: II 29 (Fr. B18b); Porphyry 1969: 8 (trad. John M. Duffy)].

Me pouparei aqui, por uma questão de espaço, de recapitular muito daquilo que Udo Reinhold Jeck escreveu em sua preciosa obra Platonica Orientalia $(2004)^{80}$, à qual remeto para uma melhor discussão da relação entre Zoroastro e Platão em Plutarco (pp. 79-82) e também para uma apreciação dos temas iranianos em Damáscio (pp. 82-86).

\section{Considerações finais}

O estudo combinado das fontes clássicas e de modernas pesquisas em iranologia garante uma melhor compreensão da antiguidade e não permite que se faça pouco caso das trocas culturais entre o Irã e a Grécia no mundo antigo, confirmando a afirmação de que "a Grécia estava mais próxima da Pérsia, e tinha mais em comum com ela do que com os norte-europeus que inventaram uma disciplina clamada [Estudos] Clássicos" (Russell 1989 1). Dentro do quadro dessa proximidade os gregos elaboraram variados retratos de Zoroastro - como profeta ou mago, como astrólogo ou como filósofo -, refletindo tanto tradições laicas como tradições religiosas, e com graus distintos de "fidelidade" em relação às suas fontes iranianas (até onde se pode reconstituí-las e interpretá-las) ${ }^{81}$. Uma ressalva de Roger Beck em relação aos contatos greco-helenísticos com o Zoroastrismo é relevante: na maior parte dos casos, o interesse maior dos autores gregos não foi o de expressar um encontro autêntico com o Zoroastrismo, mas o de "recriar e explorar outras sabedorias/sapiências estrangeiras (alien wisdoms) ${ }^{82}$ " (Beck 1991 509). Ao exegeta contemporâneo, por sua vez, cabe a tarefa de

${ }^{79}$ A identidade e a época desse Euboulos (lat. Eubulus) são incertas; no De Abstinentia (IV, 16.2) Porfírio fala de um Euboulos que "escreveu a história de Mitra em muitos livros", e que pode ter ou não sido aquele que, junto com Teodoto, chefiava a Academia por volta do ano 260, sendo contemporâneo de Porfírio [cf. H. Dörrie (1956), s. v. "Euboulos" 17a. Em: A. Pauly, G. Wissowa (eds.), Realencyclopädie der classischen Altertumswissenschaft, Supplementband 8 (1): 166-167].

${ }^{80}$ U. R. Jeck (2004), Platonica Orientalia: Aufdeckung einer philosophischen Tradition. Frankfurt, Vittorio Klostermann.

${ }^{81}$ De que essa interpretação necessita constante revisão nos dá conta W. Huard (20082009), "A Persian Influence on the Greeks?". Hirundo: the McGill Journal of Classical Studies, 7: $38-48$.

${ }^{82}$ Fora do contexto político, cultural e temporal grego, helenístico e romano. 
reconstituir e analisar as interações das diferentes tradições sapienciais antigas, avaliar suas repercussões, entender suas transformações e apreciar devidamente sua herança, explorando com olhar rejuvenescido fontes há muito conhecidas e com entusiasmo novo os achados das pesquisas mais recentes - não deixando, no entanto, de sonhar com a possibilidade de redescoberta de sabidos textos há muito perdidos ${ }^{83}$, ou de apreciar a descoberta de documentos antes desconhecidos - como o papiro de Derveni - que lançam novas luzes sobre a fascinante Cosmópolis da antiguidade.

${ }^{83}$ Como o Zoroastres de Heráclides Pôntico: "Não devemos nos esquecer que as ficções de Heráclides quase invariavelmente tinham alguma base em fatos ou na tradição anterior" (Kingsley, 1995, 188). 


\section{Bibliografia}

Aristotele (1963), Della Fillosofia. Introduzione, testo, traduzione e commento esegetico, ed. Mario Untersteiner. Roma.

Ballabio, E. (2009), Così fu Accolto Zaratustra. Roma.

Beck, R. (1991), “Thus Spake Not Zarathustra: Zoroastrian Pseudepigrapha of the Greco-Roman World", em M. Boyce, F. Grenet, A History of Zoroastrianism, III: Zoroastrianism under Macedonian and Roman rule. Leiden, 491-565.

Beck, R. (2002), "Zoroaster [part] V. As perceived by the Greeks". Encyclopaedia Iranica. Nova Iorque, Iranica on line. Em: <http:// www.iranica.com/newsite/articles/sup/Zoroaster_Greeks.html>; acedido a 03/04/2014.

Bernabé, A. (2008), "On the Rites Described and Commented upon in the Derveni Papyrus, Cols. I-VI”. Classica@, 5 (Proceedings of the Derveni Papyrus Conference, Center for Hellenic Studies, julho de 2008). Em <http:// chs.harvard.edu/CHS/article/display/5682>, acedido a 02/05/2014 [publ. ulterior em: I. Papadopoulou - L. Muellner, eds. (2014), Poetry as Initiation. Cambridge (Massachussetts)/Londres, 19-52].

Berti, E. (1997), La Filosofia del Primo Aristotele, 2a ed. Milão, Vita e Pensiero [1 $1^{a}$ ed. 1962 (Pádua)].

Bidez, J. \& Cumont, F. (1938), Les Mages Hellénisés: Zoroastre, Ostanès et Hystaspe d'Après la Tradition Grecque, 2 vols.: I: Introduction; II: Les Textes. Paris [repr. 1973].

Brandenstein, W. (1951a), "Iranische Einflüsse bei Platon". Em: Miscellania Giovanni Galbiati 3 (Fontes Ambrosiani 27). Milão, 83-88.

Brandenstein, W. (1951b), Atlantis - Größe und Untergang eines geheimnisvollen Inselreiches (Arbeiten aus dem Institut für allgemeine und vergleichende Sprachwissenschaft Graz, 3). Viena.

Cameron, A. "Agathias on the Sassanians". Dumbarton Oaks Papers, 23-24: 67184.

De Jong, A. (1997), A. Traditions of the Magi: Zoroastrianism in Greek and Latin Literature (Religions in the Graeco-Roman World 133). Leiden/N. Iorque/Colônia,.

Dio Chrysostom (1940), Discourses, 5 vols., III. Discourses XXI-XXXVI (Loeb Classical Library 358) ed. J. W. Cohoon, trad. J. W. Cohoon (discurso XXI) e H. Lamar Crosby (discursos XXXII-XXXVI). Cambridge/ Londres [repr. 1951; 1961].

Diels, H. \& Kranz, W. (1952), Die Fragmente der Vorsokratiker, 6a ed. Berlin. [1 ${ }^{\mathrm{a}}$ ed. 1906 (Berlim)]. 
Dillon, J. (2003), The Heirs of Plato: A Study of the Old Academy (347-274 BC). Oxford. [repr. 2005].

Diogenes Laërtius (1972). Lives of Eminent Philosophers, 2 vols., trad. e notas R. D. Hicks. Cambridge [1 ${ }^{\mathrm{a}}$ ed. 1925 (Londres/Nova Iorque)].

Dumoulin, B. (1981), Recherches sur le premier Aristote (Eudème, de la Philosophie, Protreptique). Paris.

Eliade, M. (1992), Mito do Eterno Retorno, trad. J. A. Ceschin. São Paulo [orig. 1949].

Fox, W. S. \& Pemberton, R. E. K. (1929), "Passages in Greek and Latin Literature Relating to Zoroaster and Zoroastrianism Translated into English". Journal of the K. R. Cama Oriental Institute (Bombaim), 14 (ed. D. B. Taraporevala; 145 pp.).

Jackson, A. V. W. (1899), Zoroaster, The Prophet of Ancient Iran. Nova Iorque [repr. 1901 (Londres)].

Jacoby, F. (ed.) (1923-1959), Die Fragmente der griechischen Historiker [FGrH]. Berlim.

Jacoby, F. Bollansée, J. Engels, J. Schepens, G. \& Theys, E. (eds.) (1998), Die Fragmente der griechischen Historiker continued, part IV: Biography and antiquarian literature, edited by G. Schepens, IVA: Biography, Fascicle I: The Pre-Hellenistic Period. Leiden/Boston/Colônia.

Jaeger, W. (1947), Aristóteles: bases para la historia de su desarrollo intelectual, trad. J. Gaos. México [orig. 1923].

Kingsley, P. (1995), "Meetings with Magi: Iranian Themes among the Greeks, from Xanthus of Lydia to Plato's Academy". Journal of the Royal Asiatic Society, 5 (Ser. 3): 173-209.

Millar, F. (1988). "Looking East from the Classical World: Colonialism, Culture, and Trade from Alexander the Great to Shapur I". International History Review, 20 (3): 507-531 [Disponível em <http://berlinarchaeology.files. wordpress.com/2013/01/millar-1998.pdf >].

Molé, M. (1963), Culte, Mythe et Cosmologie dans l'Iran Ancien, 2 vols. Paris, Presses Universitaires de France.

Müller, K. \& Müller, Th. (eds.) (1841), Fragmenta Historicorum Graecorum [FHG], I. Paris, Ambrose Firmin Didot.

Panoussi, E. (1968), "La teosophie iranienne source d'Avicenne?". Revue Philosophique de Louvain, 66 (90): 239-266.

Pirart, E. (2010), Les Adorables de Zoroastre - Textes avestiques traduits et présentés. Paris.

G. [ou C.] Plinius Secundus (1875-1906), Naturalis Historiae Libri XXXVII [Naturalis Historia], ed. Karl Friedrich Theodor Mayhoff, 5 vols., vol. 
4 (livros 23-30; 1897). Leipzig, B. G. Teubner [Disponível em <http:// www.perseus.tufts.edu/hopper/text;jsessionid=90BF5AEC27180D1A3 1F1D738D1D8D324?doc=Perseus\%3atext\%3a1999.02.0138>].

Porphyry (1969), The Cave of the Nymphs in the Odyssey. A revised text with translation (Arethusa Monographs, vol. 1), ed. L. G. Westerink e "Seminar Classics 609”. Búfalo.

Puech, H.-C. (1952), "L'Iran et la philosophie grecque”. Em: H. Massé (ed.), La Civilisation Iranienne. Paris, 80-90.

Rose, J. (2000), The Image of Zoraster: the Persian mage through European eyes. Nova Iorque.

Russell, J. R. (2001), "The Magi in the Derveni Papyrus". Nāme-ye Irān-e Bāstān, 1 (1): 49-59 [Disponível em <http://www.kavehfarrokh.com/ wp-content/uploads/2010/12/russel.pdf >]

Russell, J. R. (1989), "The Republic of Plato and What It's All About" ["The Republic of Plato and What It's All About", "On the Books of Isaiah", and "Job and the Question of Evil". Columbia College Humanities Seminar, 1988-9]. Nova Iorque.

Suidas (1928-1938), Suidae Lexicon: Graecè et Latinè [= Soũda; Suda], 5 vols., ed. A. Adler. Stuttgart, Teubner. Em: < http://www.stoa.org/sol/>, acedido a 03/04/2014.

Vasunia, P. (2007), Zarathushtra and the Religion of Ancient Iran: The Greek and Latin Sources in Translation. Bombaim.

Voegelin, E. (2000), Collected Works, vol. 16: Order and History, Volume III: Plato and Aristotle, ed. D. L. Germino. Columbia [orig. 1957]. 